\title{
PAR TAUTAS TIESĪBĀM UN FAKTISKĀM IESPĒJĀM GROZĪT LATVIJAS REPUBLIKAS SATVERSMI
}

\section{ON PEOPLE'S RIGHTS AND ACTUAL CAPACITY TO AMEND THE CONSTITUTION OF THE REPUBLIC OF LATVIA}

\author{
Ringolds Balodis, Dr. iur. \\ LZA korespondētājloceklis, Latvijas Universitātes Juridiskās fakultātes \\ Valststiesību zinātņu katedras profesors
}

\begin{abstract}
Zinātniekiem un vēlētājiem, kuri kādreiz lasīs Satversmi, atliksies tikai pavīpsnāt par to likumdošanas iestādi, kura ir it kā gribējusi tautai dot kādas demokrātiskas tiesības, bet patiesībā pasniegusi vinai tukšu roku. Praksē pierādīsies, ka faktiski referenduma tiesības nevarēs tikt izlietotas.
\end{abstract}

(Satversmes sapulces loceklis Kārlis Dzelzītis)

\begin{abstract}
Summary
The article is dedicated to the mechanism - procedure for amending Latvian Constitution - Satversme. Satversme guarantees the people (totality of citizens) the right to amend Satversme in the procedure of referendums. The aim of the article is to clarify whether the people of Latvia really have means to amend Satversme, or is this right just a formal notion, and not enforceable in reality. The author explores whether the constitutional legislator, aiming to ensure constitutional stability, has not set an exaggeratedly high quorum of voters' participation in the referendum for all articles of the Satversme, and whether the mechanism of referendum in Latvia has not become incapable of functioning.
\end{abstract}

Atslēgvārdi: Satversme, konstitūcijas grozī̌sanas apgrūtinājumi, Satversmes grozījumi, Satversmes grozišanas kārtība, Satversmes pamata panti, tautas nobalsošana, dalïbas un apstiprināšanas kvorumi tautas nobalsošanā.

Keywords: the Satversme (Constitution), impediments to amending constitutions, amendments to the Satversme, procedure for amending the Satversme, basic articles of the Satversme, referendum, participation and approval quorums in a referendum.

\footnotetext{
${ }^{1}$ Dzelzītis K. Satversmes sapulces sēžu stenogrammas, piemēram, Satversmes I daḷas lasī̌̌ana pa pantiem. V sesijas 14. sēde 1922. gada 15. februārī, stenogramma. Latvijas Satversmes sapulces stenogrammu izvilkums (1920-1922). Latvijas Republikas Satversmes projekta apspriešana un apstiprināšana [elektr. izd.]. Rìga: Tiesu namu aǵentūra, 2006, 850. lpp.
} 


\section{Ievads}

Kārotāju pēc Latvijas teritorijas 1917.-1919. gadā netrūka. Vācija pēc revolūcijas bija nodarbināta ar sevi, tāpat kā Krievija, kur jau pilnā sparā notika Pilsoṇu karš. Redzamākie pretendenti bija Tautas padome, kuru prezentēja pagaidu valdība ar Kārli Ulmani priekšgalā, baltvāciešu lobētais luterāṇu mācītājs Andrievs Niedra un sarkano strēlnieku balstītais Pēteris Stučka. Tautas padome, kas galarezultātā arī izcīnīja Latvijas valsti, atšḳ̄inās no citiem valstiskuma pretendentiem, pirmkārt, jau ar to, ka pirmā vietā izvirzijja demokrātiskas valsts ideju, kas balstās uz vienlīdzīgās, vispārīgās, tiešās un aizklātās vēlēšanās iegūtu delegeējumu. Šāds nodoms, kas izskatās pašsaprotams no mūsdienu skata punkta, 1918. gada nogalē jāuzskata par progresīvu (dzimumu līdztiesība politiskajās tiesībās) un drosmīgu, jo vēlēšanu ceḷā pie varas tikpat varēja nonākt komunisti. Vēlēšanas sarīkot nebija padomā ne Niedram, kurš plānoja kūriju (sociālo slāṇu un nacionālo minoritāšu) vēlēšanas, ${ }^{2}$ nedz arī Stučkam, kurš vēlēšanas rīkotu, taču neḷaujot tajās piedalīties komunistu ienaidniekiem. Pretēji tam nacionālā inteliǵence un pilsoniskā sabiedrība valsts dibināšanas dokumentos svētsvinīgi solīja pašai tautai caur speciāli šim nolūkam ievēlētiem delegātiem lemt par jaunās valsts pamatlikumu. ${ }^{3}$ No šāda viedokḷa Latvijas Republikas Satversmē (turpmāk - Satversme) ${ }^{4}$ bija saprotami paredzēt pilsoṇu tiesības grozìt pamatlikuma normas. Satversmi pieņemot, virknē pantu (72., 73., 74., 75., 77., 79. un 80. pants) tika paredzētas tautas specifiskas tiesības un pienākumi likumdošanas procesā. Satversmē ir nostiprināti divi likumdevēji - parlaments un pilsoṇu kopums. Parlaments ir primārais likumdošanas varas orgāns, kuru tauta ievēlē ikdienas darbiem, kamēr tauta savas tiesības īsteno tikai atsevišķos Satversmē noteiktajos gadijumos.

Raksta autors centīsies rast atbildi uz jautājumu, vai Satversmes veidotāji ir pareizi izsvēruši tautas faktiskās iespējas piedalīties konstitucionālajā likumdošanā, kas tiek realizētas ar tautas nobalsošanu starpniecību. Autora ieskatā, ir pienācis laiks objektīvi izvērtēt pilsoṇu kopuma uzkrāto pieredzi likumdošanas jomā, jo vienpadsmit tautas nobalsošanas, tā Saeimas pieņemtie piecpadsmit Satversmes grozījumi dod pietiekošu vielu pārdomām, lai varētu izdarīt secinājumus par Satversmē tautai garantēto tiesību praktisko realizāciju.

\section{Satversmes grozī̌sanas divas kārtības un to bilance}

Par Satversmē iestrādāto Satversmes grozījumu formulu un tautas nobalsošanas noregulējumu, tāpat kā ar tiem saistītiem kvorumiem mēs esam pateicību parādā Satversmes sapulces loceklim Paulam Šīmanim. Baltvācieša priekšlikums, kas, visticamāk, bija noskatīts no 1919. gada Veimāras konstitūcijas, ${ }^{5}$ Satversmes

2 Balodis R., Lazdinš̌ J. Satversmes vēsturiskā attīstība. Latvijas Republikas Satversmes komentāri. Ievads. I nodaḷa. Vispārējie noteikumi. Autoru kolektīvs prof. R. Baloža zinātniskā vadỉbā. Rīga: Latvijas Vēstnesis, 2014, 54.-55. lpp.

3 1. punkts. Latvijas pilsoņiem!: Tautas Padomes Latvijas Republikas proklamēšanas akts (18.11.1918.). Latvijas Pagaidu Valdỉbas Likumu un Rỉkojumu Krājums, 15.07.1919., Nr. 1; 1. panta pirmais punkts. Tautas padomes politiskā platforma. Pieņemta Latvijas Tautas Padomes sēdē 17.11.1918. Valdības Vēstnesis, 14.12.1918., Nr. 1; Latvijas Pagaidu Valdības Likumu un Rỉkojumu Krājums, 15.07.1919., Nr. 1.

${ }^{4}$ Latvijas Republikas Satversme: LV likums. Pieṇemts 15.02.1922. Valdības Vēstnesis, 1922, Nr. 141.

5 Sk. Vācijas 1919. gada 11. augusta konstitūcijas 74., 75. un 76. pantu. Pieejams: http://hydrastg.library. cornell.edu/fedora/objects/nur:01840/datastreams/pdf/content 
komisijā tiek saskaldīts atsevišḳās normās, ${ }^{6}$ lai galarezultātā iegūtu pašreizējo Satversmes normu numerāciju, attiecīgi 76., 77., 78. un 79. pants, kuros ir algoritmēta Satversmes grozī̌̌anas kārtība:

1. Satversmes grozǐšanas kārtība parlamentā. Satversmes procedūras Satversmes grozīšanai Saeimā ir noteiktas 76. pantā. Pirmkārt, pants noteic, ka, grozot Satversmi, Saeimai ir jāievēro "trīs lasījumu nosacījums"7 ("steidzamības neiespējamības princips”). ${ }^{8}$ Otrkārt, Satversmi grozot, jāievēro divu trešdaḷu deputātu klātesamības ${ }^{9}$ un apstiprināšanas kvorumi, kas domāti, no vienas puses, lai Satversmi aizsargātu no nepārdomātiem grozijumiem, no otras puses, lai to apstiprināšanā būtu iesaistīta lielākā daḷa deputātu, kas faktiski nozīmē, ka Saeimas koalīcijai pēc būtības ir jāspēj vienoties par grozījumiem ar opozīciju. "Piepildīts kvorums"10 kalpo "pareizas izteiksmes"11 un "nepārprotamas gribas"12 noskaidrošanai, kas ir svarīgi, lai Satversmē neiekḷūtu ar mirkḷa emocijām saistītas normas. Kvorums no konstitucionālo tiesību viedokḷa pilda svarīgu lomu. Kvoruma lietderība sakņojas tautvaldības būtībā, jo neḷauj kādai nelielai grupai uzspiest vairākumam savu kārtību pret vairākuma gribu. Svarīgi piezīmēt, ka, ja kvorums tiek noteikts pārāk augsts un nesasniedzams, tas var kalpot tieši pretēji un būt par šḳērsli jebkuram kolektīvam lēmumam, tā iekonservēt konstitucionālo attīstību un veicināt stagnāciju. Atškirīibā no daudzām citām valstīm, ${ }^{13}$ Satversmi nav liegts grozìt ārkārtējo situāciju un iznēmuma stāvokḷa laikā. Satversmes tiesa ir nostiprinājusi praksi, ${ }^{14} \mathrm{ka}$ satversmiskajā likumdošanas procesā priekšlikumus var iesniegti vienīgi par tiem pantiem (attiecīgi par to pantu grozišanu vai izslēgšanu), kas likumprojektā ir apstiprināti pirmajā lasījumā. Vēl jāpiebilst, ka Satversmes grozijumus Latvijā var rosināt tie paši subjekti, kam uz to tiesības vispārējā likumdošanas procesā.

2. Satversmes grozišana referendumā ir atrunāta 77. un 79. pantā, kamēr likums "Par tautas nobalsošanu, likumu ierosināšanu un Eiropas pilsoṇu

\footnotetext{
${ }^{6}$ Latvijas Satversmes sapulces Satversmes komisijas 1. apakškomisijas 17.01.1921. sēdes protokols Nr. 8.

7 Tai pašā laikā par būtisku trūkumu jāuzskata tas, ka Satversmes grozijumiem nav noteikts laika intervāla ierobežojums starp šiem lasījumiem. Tas l̦auj populistiskos nolūkos izmantot konstitucionālus jautājumus. Vislabāk to ilustrē Satversmes piecpadsmitais grozijjums (2018), kas korig̣ēja Satversmes 36. pantā noteikto Valsts prezidenta ievēlēšanas kārtību - mainot aizklāto ievēlēšanu uz atklāto. Trešais lasījums tika pieṇemts vien divas dienas (!!!) pirms 13. Saeimas vēlēšanām! Atbildīgai Saeimas komisijai Satversmes grozijjumu likumprojekts nodots 17. maijā, pirmais lasījums notika 6. septembrī, otrais jau pēc mēneša 20. septembrī, bet noslēdzošais trešais - 4. oktobrī. 3. Saeimas vēlēšanas notika 6. oktobrī! Rekordliels ātrums ir raksturīgi arī četrpadsmitiem Satversmes grozījumiem (2009), kas svītroja no Satversmes 30. panta deputātu administratīvo imunitāti. Komisijai likumprojekts nodots 15. martā, pirmais lasijums notika 4. aprīlī otrais 19. aprīlī, bet trešais - 3. maijā.

${ }^{8}$ Balodis R., Kuzņecovs A. Satversmes 76. panta komentārs. Latvijas Republikas Satversmes komentāri. V nodal̦a. Likumdošana. Autoru kolektīvs prof. R. Baloža zinātniskā vadībā. Rīga: Latvijas Vēstnesis, 2019, 214. lpp.

${ }^{9}$ Lai Satversmes grozī̌̌anas sēde Saeimā būtu legitīma, tajā jāpiedalās vismaz 67 deputātiem, kas ir divas trešdalıas jeb absolūtais Saeimas deputātu vairākums.

${ }^{10}$ Latvijas Republikas IV Saeimas V sesijas 4. sēde 1933. gada 10. februārī. Latvijas Republikas IV Saeimas V sesija. 1933. gads. Rīga: Latvijas Republikas Saeimas izdevums, 149.-150. lpp.

11 Dišlers K. Ievads Latvijas valststiesību zinātnē. Rīga: Tiesu namu aǵentūra, 2017, 148. lpp.

12 Latvijas Republikas IV Saeimas V sesijas 4. sēde 1933. gada 10. februārī. Latvijas Republikas IV Saeimas V sesija. 1933. gads. Rīga: Latvijas Republikas Saeimas izdevums. 149.-150. lpp.

13 Sk., piemēram, Lietuvas konstitūcijas 147. pantu. Pieejams: https://www.constituteproject.org/constitution/Lithuania_2006?lang=en

14 Satversmes tiesas 16.12.2008. spriedums lietā Nr. 2008-09-0106, 16.5. punkts.
} 
iniciatīvu"15 nosaka vietējo pašvaldību un Centrālās vēlēšanu komisijas iesaisti referendumu organizēšanā, procedūras, termiṇus un kārtību vēlētāju parakstu vākšanai, balsošanai un balsu skaitī̌̌anai. Satversmes 78. pantā savukārt ir noteiktas tautas tiesības rosināt Satversmes grozījumus (var veikt, ja savākta $1 / 10$ vēlētāju parakstu), bet 77. pants paredz ìpašu kārtību Satversmes pamata pantu (1., 2., 3., 4., 6. vai 77. panta) grozī̌sanā. Tos var grozìt tikai tautas nobalsošanā, un Satversmes 79. panta pirmā daḷā ir nostiprināts Satversmes grozījuma apstiprināšanas kvorums - "puse no visiem balsstiesīgajiem".

Vislabāk to, kādas faktiskās iespējas ir tautai Satversmes un vispārējā likumdošanā, parāda bilance, kas skarbi un lakoniski norāda uz radušos tālākās attīstības strupcelu. Tauta (0) : Saeima (15), jo neviena no Satversmes normām nav pieņemta tautas nobalsošanas ceḷā. Tās visas ir grozītas Saeimā 76. panta kārtībā. Cenšoties rast atbildi uz jautājumu, vai tiešām Satversmes autori vēlējās tautvaldības dekorāciju, Satversmes sapulces stenogrammās var lasīt P. Šīmaṇa un viṇa priekšlikuma atbalstītāju paustos uzskatus. Augstais kvorums "puse no visiem balsstiesīgajiem" tika pamatots ar to, ka tautai pie Satversmes ķerties vajadzētu "tikai nopietnos gadījumos" un "ar skaidru pārliecību” par grozījumu nepieciešamību. Lai saprastu, ka tauta patiešām vēlas grozìt Satversmi, tā "jāsaspīlē" ar augsta kvoruma palīdzību. ${ }^{16}$ No vienas puses, ir grūti apšaubìt šo motivāciju, taču, lai saprastu, vai nav notikusi pārliecīga "saspīlēšana", meklēsim atbildes faktos, skaitḷos un stenogrammās.

\section{Tautas apsardzība, Satversmes 77. pantā uzskaitītās normas grozot}

Ja Saeima grozījusi Satversmes 77. pantā uzskaitītos Satversmes pamata pantus, attiecīgi 1., 2., 3., 4., 6. vai 77. pantu, ${ }^{17}$ tad, lai grozījums varētu stāties spēkā, tas tautas nobalsošanā jāapstiprina otram konstitucionālajam likumdevējam tautai. Kārlis Dišlers to nodēvēja par "tautas apsardzību", 18 jo Saeima bez tautas nevar vienpersoniski lemt par Satversmes kodola pārgrozǐšanu. Respektīvi, pat gadījumā, ja Saeimā vairākumu veidotu tādi politiski spēki, kuri spētu nodrošināt 76. pantā noteiktos kvorumus, viṇu ieceres fundamentāli mainìt teritoriju, politisko sistēmu un valsts valodu paliktu vien ieceres līmenī, lìdz kamēr tauta to neapstiprinātu tautas nobalsošanā. Papildus šai, Dišlera vārdiem runājot, tautas apsardzībai tiesību doktrīna ir attīstijusi ideju par Satversmes pamatu, valsts pamatu aizsardzību no pašas tautas. "Pašaizsargājošās demokrātijas princips" aizsargā no "valsts pašnāvības", kas var notikt "legālas revolūcijas" ceḷā, lai viens atsevišķs Satversmes grozījums, kuram būtu tautas nobalsošanā "acumirklīgs demokrātisks vairākums”, nesagrautu Satversmes pamatos liktās vērtības un latviešiem uz mūžiem liegtu juridisku tiesību uz valstiskās pašnoteikšanās iespēju,

15 Par tautas nobalsošanu, likumu ierosināšanu un Eiropas pilsoṇu iniciatīvu: LV likums. Latvijas Vēstnesis, 20.04.1994., Nr. 47 (178).

16 Latvijas Republikas IV Saeimas V sesijas 4. sēde 1933. gada 10. februārī. Latvijas Republikas IV Saeimas V sesija. 1933. gads. Rīga: Latvijas Republikas Saeimas izdevums, 149. lpp.

17 Satversmes tiesa šai sakarā ir gājusi vēl tālāk un atzīmējusi, ka tautas nobalsošanas Satversmes 77. panta kārtībā ir rīkojamas arī tad, ja parlaments "pēc būtības" pārgroza kādu tiesību aktu, aizskar arī minētā Satversmes panta aizsardzībā esošas normas, piemēram, pieņemot likumu par kāda starptautiska līguma ratifikāciju, kuri aizskar Satversmes 1. un 2. pantā noteikto (Satversmes tiesas 07.04.2009. spriedums lietā Nr. 2008-35-01, 15.1., 15.2. punkts).

18 Dišlers K. 2017, 143. lpp. 
ko zaudējot atgūt vairs nebūs iespējams. ${ }^{19}$ Šo pieeju sauc arī par neaizskaramā Satversmes kodola koncepciju, un tā nolasāma no Satversmes ievada pirmās rindkopas formulējuma "latviešu nācijas negrozāmā valstsgriba"20. Augstākā tiesa ar 2013. gada 30. aprīḷa, 2014. gada 12. februāra un 2014. gada 28. marta spriedumu šo pieeju ir nostiprinājusi vēl fundamentālāk. 2013. gada 30. aprīḷa spriedumā Augstākā tiesa atzīst Centrālās vēlēšanas komisijas un tiesas lielāku iesaisti, vērtējot tautas nobalsošanai iesniegto likumprojektu izstrādātību, norādot, ka valsts institūcijām ir neapšaubāmas tiesības novērst demokrātijas apdraudējumu jau agrīnā stadijā. ${ }^{21}$ N̦emot vērā, ka iniciatīvas grupas iesniegtā likumprojekta tekstu turpmākajā procesā vairs nevar grozìt, Augstākā tiesa 2014. gada 12. februāra spriedumā norāda, ka Centrālai vēlēšanu komisijai ir jānodrošina tas, lai tautas nobalsošanai netiktu virzìts tāds projekts, kas ir pretrunā ar demokrātiskas un tiesiskas valsts pamatvērtībām. ${ }^{22}$ 2014. gada 28. marta spriedumā Augstākā tiesa ir norādījusi, ka pilsoṇu kopuma iniciēts Satversmes grozijumu projekts, lai to varētu uzskatīt par "pilnīgi izstrādātu", pēc sava satura nedrīkst būt pretrunā ne ar tiem Satversmes noteikumiem, kurus tas nepiedāvā grozìt, ne ar Satversmes kodolu. ${ }^{23}$ Tāpat minētā spriedumā Augstākā tiesa skaidro, ka daḷa no nerakstītiem vispārējiem tiesību principiem un pamatvērtībām, uz kurām balstās Satversme, veido Satversmes kodolu. Tas aptver elementus, kas veido Latvijas valsts identitāti un Latvijas demokrātiskās valsts iekārtas identitāti. ${ }^{24}$ Vērts pieminēt, ka citviet Eiropas Savienībā "neaizskaramo pantu" vai t. s. pantu ar "mūžības klauzulu" (Ewigkeitsklausel) aizsardzība tiek risināta visdažādākos veidos, ${ }^{25}$ taču ierasta lieta ir to nostiprināšana konstitūcijā, paredzot sarežğìtāku grozīšanas kārtību. ${ }^{26}$ Latvijā liktenīgs izrādỉjās 2012. gads, kad tautas nobalsošanā tautai bija jāizšḳiras par otru valsts valodu "valodas referendumâ". ${ }^{27}$

19 Sk.: Levits E. Eiropas Savienība kā vērtību savienība. Jurista Vārds, 08.05.2018., Nr. 19; Levits E. Valstsgriba. Idejas un domas Latvijai 1985-2018. Latvija Vēstnesis, 2019, 565., 592., 619., 638. un 835. lpp.; Briede J. Satversmes 78. panta komentārs. Latvijas Republikas Satversmes komentāri. V nodaḷa. Likumdošana. Autoru kolektīvs prof. R. Baloža zinātniskā vadībā. Rīga: Latvijas Vēstnesis, 2019, 286. lpp.; Pleps J., Pastars E., Plakane I. Konstitucionālās tiesības. Papildināts un pārstrādāts izdevums. Rīga: Latvijas Vēstnesis, 2014, 56. lpp.

${ }^{20}$ Meistere D. Saeimas Juridiskā biroja atzinums par Satversmes ievada pieṇemšanas procedūru. Jurista Vārds, 08.07.2014., Nr. 26, 12.-13. lpp.

21 Augstākās tiesas Senāta Administratīvo lietu departamenta 30.04.2013. sprieduma lietā SKA-172/2013 motivu dal̦as 20. punkts.

22 Augstākās tiesas Administratīvo lietu departamenta 12.02.2014. sprieduma lietā Nr. A420577912 SA$1 / 2014$ motivu dal̦as 8 . punkts.

23 Augstākās tiesas Administratīvo lietu departamenta 28.03.2014. sprieduma lietā SA-3/2014 motīvu dal̦as 12. punkts.

24 Turpat.

25 Unconstitutional Constitutional Amendments. The Limits of Amendment Powers. Marin Loughlin, John P. McCormick and Neil Walker (eds.). Oxford University Press. United Kingdom, 2017, pp. 23-26.

${ }^{26}$ Latvijas Republikas Satversmes komentāri. V nodal̦a. Likumdošana. Autoru kolektīvs prof. R. Baloža zinātniskā vadībā. Rīga: Latvijas Vēstnesis, 2019, 205., 262.-265. lpp.

27 2012. gada 18. februārī Latvijā notika tautas nobalsošana par likumprojekta "Grozījumi Latvijas Republikas Satversmē” pieņemšanu. Likumprojekts paredzēja mainīt Satversmes 4., 18., 21., 101. un 104. pantu, iekḷaujot tajos nosacijumu par krievu valodu kā otru valsts valodu, nosakot, ka arī pašvaldỉbās darba valodas ir latviešu un krievu valoda un ikvienam ir tiesības saṇemt informāciju latviešu un krievu valodā. Tautas nobalsošanas zīmē bija jautājums "Vai jūs esat par likumprojekta "Grozijjumi Latvijas Republikas Satversmē” pieņemšanu, kas paredz krievu valodai noteikt otras valsts valodas statusu?”. Iespējamie atbilžu varianti bija "Par" un "Pret". Pieejams: https://www.cvk.lv/lv/tautas-nobalsosanas/par-grozijumiem-latvijas-republikas-satversme-2012. [aplūkots 04.09.2020.]. 
Par Satversmes 77. pantā noteikto Satversmes pamata panta aizsardzību un Satversmes kodola konceptu vēl ir jāatzīmē, ka pilnībā nav noraidīts arī viedoklis, ka Satversmes 77. panta primārais mērḳis tomēr ir "izṇemt” noteiktus jautājumus no Saeimas kompetences, bet ne no tautas kompetences, jo tautai ir tiesības lemt par savas valsts pamatiem ${ }^{28}$ un nevajadzētu noraidìt atsevišķu Satversmes kodola elementu izvērtēšanu tautas nobalsošanā. ${ }^{29}$ Tas liek domāt, ka, neesot skaidram normativvajam regulējumam, Satversmes kodola neaizskaramība ir l̦oti atkarīga no atbildīgo amatpersonu, tiesnešu personīgās pārliecības. Prakse vēl ir veidošanās stadijā, un Satversmes kodola koncepta aizsardzības elementu (tai skaitā arī Satversmes ievadam) pārbaudījums vēl tikai priekšā. Noslēdzot šo sadaḷu, var secināt, ka Satversmes kodolam ir praktiski dubulta aizsardzība, jo Satversmes pamata pantus grozìt var tikai tautas nobalsošanā ar l, loti augstu kvorumu (Satversmes 79. panta pirmais teikums), turklāt arī tautai nav tiesību veikt demokrātiskas valsts pašiznīcināšanās aktu. Vai šāda aizsardzība ir jēgpilna vai pārspīlēta attiecībā uz visas Satversmes normām, ir jautājums, ko noskaidrosim raksta noslēgumā.

\section{Tautas apsardzība vai aizsardzība no tautas?}

Sākotnējam konstitucionālajam likumdevējam - Satversmes sapulces vairākumam - nebija būtisku iebilžu par Satversmes 79. panta pirmajā teikumā noteikto kvoruma lielumu. Diskusijas par referendumu problemātiku bija minimālas. Acīmredzot kvorums "puse no visiem balsstiesīgajiem” šķita pieņemams, ņemot vērā Satversmes sapulces ievēlēšanas datus, jo 1920. gada Satversmes sapulces vēlēšanās piedalījās $84,9 \%$ balsstiesīgo vēlētāju (677 084). ${ }^{30}$ Satversmes sapulces vēlēšanas, kā jau pirmās vēlēšanas jaundibinātā valstī, bija valstiskā romantisma apvītas, un laikam jau Satversmes tēviem toreiz varēja šksist, ka tā bùs vienmēr, un, ja tautai jautājums būs svarīgs, tad gan kvorums "radīšoties un tautas nobalsošana varēs notikt" 31 . Tomēr ar tautas nobalsošanām negāja arī pirmskara Latvijā, mūsdienās tās pavisam ir "uzkārušās". Mūsdienu realitāte ir krietni piezemētāka un ar daudz mazākām cerībām uz statistikas uzlabošanu, par ko liecina Rīgas pašvaldību vēlēšanas 2020. gadā, kur pie vēlēšanu urnām devās vien 40,6\% iedzīvotāju. Pēdējās 13. Saeimas vēlēšanās (un, kā zināms, referendumi pulcē krietni mazāku vēlētāju skaitu) 2018. gadā piedalījās vien 54,6\% balsstiesīgo vēlētāju (844 925). Šobrīd, lai noorganizētu referendumu ar nodomu grozìt Satversmi, organizatoram ir jāapzinās, ka "par" Satversmes grozījumiem ir jānobalso 774337 balsstiesīgajiem vēlētājiem. Šādu skaitli mēs iegūstam, sadalot skaitli 1548 673, - tas ir balsstiesīgo skaits, kas bija tiesīgs vēlēt pēdējās 13. Saeimas vēlēšanās. Minētais liek pievienoties ekspertu viedoklim par to, ka Satversmes grozī̌sanu referendumā ir jāuzskata par teorētisku iespējamību. ${ }^{32}$ Ja pieņemam, ka jebkuras valsts pamatlikums būtībā ir pašas tautas vienošanās par valsts varas formu,

${ }_{28}$ Nikulceva I. Satversmes 77. panta komentārs. Latvijas Republikas Satversmes komentāri. V nodaḷ. Likumdošana. Autoru kolektīivs prof. R. Baloža zinātniskā vadībā. Rīga: Latvijas Vēstnesis, 2019, 271. lpp.

29 Paparinskis M. Piezīmes par Satversmes preambulas projektu. Jurista Vārds, 22.10.2013., Nr. 43.-36. lpp.

30 Pieejams: https://www.cvk.lv/lv/velesanas/saeimas-velesanas/satversmes-sapulces-velesanas.

31 Vispārējās debates par Satversmes I daḷu, IV sesijas 5. sēde 1921. gada 28. septembrī, stenogramma. Latvijas Satversmes sapulces stenogrammu izvilkums 1920-1922. Latvijas Republikas Satversmes projekta apspriešana un apstiprināšana [elektr. izd.]. Rīga: Tiesu namu aǵentūra, 2006, 129. lpp.

32 N̦ikuḷceva I. 2019, 269. lpp. 
pārvaldes principiem un institūcijām, tad tautai ir jābūt tiesībām uz šìs vienošanās pārgrozījumiem - tiesībām uz satversmes varu. Ar 90\% garantiju varam prognozēt, ka tautas nobalsošana par deputātu imunitātes atņemšanu, Saeimas deputātu skaita samazināšanu, Valsts prezidenta pilnvaru vai ievēlēšanas grozījumiem, Ministru kabineta normām un par jebkuru citu jautājumu ir lemta neveiksmei. Kāpēc? Tas nav pareizi, it ìpaši jau Latvijā, kur valsts tika būvēta uz Satversmes sapulces ievēlēšanas solījuma valsts dibināšanas dokumentā. Tautas tiesībām ir jābūt reālām, nevis tādām, kas nav realizējamas, jo Satversme garantē Latvijas tautas ekskluzīvās tiesības rīkoties ar Satversmes fundamentālajām normām, kamēr Saeimai ir vien Satversmes caurlūkošanas vara, kas ir atšķirīga no Latvijas tautas satversmes varas. ${ }^{33}$

To, ka satversmiskais kvorums "puse no balsstiesīgajiem" ir praktiski "nepiepildāms", labi ilustrē arī divi no piecpadsmit Satversmes grozījumiem:

1) 4. Saeima 1933. gadā groza Satversmes 74. un 79. pantu, samazinot dalības un apstiprināšanas kvorumus tautas nobalsošanai nodotiem likumprojektiem. Turpmāk dalības kvorums (agrāk bija jāpiedalās "pusei no visiem balsstiesīgajiem”) tiek noteikts "puse no pēdējās Saeimas vēlēšanās piedalījušos vēlētāju skaita", bet apstiprināšanas kvorums (agrāk nebija īstas skaidrības, vai "par" jānobalso "pusei no visiem balsstiesīgajiem" vai vienkāršam vairākumam) tiek noteikts "vairākumam no vēlēšanās piedalījušos vēlētāju skaita”. Satversmes grozījumu Saeima pieņem pēc gandrīz desmit gadu ilgušām debatēm starp Valsts prezidentiem, Saeimām un Centrālo vēlēšanu komisiju, kuras raisa pirmās trīs kvorumu dēl izgāzušās tautas nobalsošanas $(1923,1927,1931) ; 34$

2) 8. Saeima 2003. gadā groza Satversmes 68. un 79. pantu, paredzot īpašu tautas nobalsošanu iestājai Eiropas Savienībā un nosakot dalības kvorumu "puse no pēdējās Saeimas vēlēšanās piedalījušos vēlētāju skaita" un apstiprināšanas kvorumu "vairākums no vēlēšanās piedalijušos vēlētāju skaita”. Grozījumu iestrādāšanu Satversmē veicināja ārkārtīgi lielā politiskā griba iestāties Eiropas Savienībā. Pasākums notika, apejot 77. panta kārtību, lai gan runa ir par būtisku suverenitātes pašierobežošanu. Respektīvi, Satversmes 2. pants grozìts netika un būtiski jaunais kvorums bija jau realizējams, ${ }^{35}$ lai arī ar masīvu valsts atbalstìtu reklāmu.

Noslēgumā ir vērts atzīmēt, ka aplūkojamais jautājums nav saistīts tikai ar satversmiskiem kvorumiem, bet arī ar pašu referendumu noregulējumu. 2012. gada referendums par otro valsts valodu - krievu valodu - lika Saeimai izšķirties par tādiem grozījumiem likumā kā "Par tautas nobalsošanu, likumu ierosināšanu un Eiropas pilsoṇu iniciatīvu", ${ }^{36}$ kas galarezultātā tautas nobalsošanas apturēja lìdz pat mūsu dienām. Annija Kārkliṇa šai sakarā ir atzinusi, ${ }^{37}$ ka tautas nobalsošanas

33 Satversmes tiesas 07.04.2009. spriedums lietā Nr. 2008-35-01, 15.1., 15.2. punkts. Satversmes tiesas 29.11.2007. spriedums lietā Nr. 2007-10-0102, 31.1. punkts.

${ }^{34}$ Balodis R., Kuzṇecovs A. Latvijas Republikas Satversmes grozijums Nr. 1. Latvijas Republikas Satversmes komentāri. V nodaḷa. Likumdošana. Autoru kolektīvs prof. R. Baloža zinātniskā vadībā. Rīga: Latvijas Vēstnesis, 2019, 220.-221. lpp.

35 Skatīt vairāk turpat, 238.-239. lpp.

36 Grozijumi likumā "Par tautas nobalsošanu, likumu ierosināšanu un Eiropas pilsoṇu iniciatīvu": LV likums. Pieñemts 08.11.2012. Latvijas Vēstnesis, 27.11.2012., Nr. 186 (4789).

37 Kārkliņa A. Requirements to be Set for Voters' Legislative Initiatives in the Republic of Latvia: Legal Regulation, Practice, and Recent Findings of Judicature. Journal of the University of Latvia, e / Law, 2017, No. 10, pp. 154-155. 
procedūra Latvijā kaut kā nebūt tomēr darbojās līdz brīdim, kad tos izbeidza 2012. gada grozijumi. Aivars Ozoliņš to raksturoja šādi: "politiķu iedoma aizstāvēt valsti no tās pilsoṇiem, ierobežojot viṇu tiesības, ir slikts uzvedỉbas stils. [..] Likumprojekta autori risina neesošu problēmu un mēgina novērst nevis kādas nevēlamas referendumu sekas, bet gan iespēju tos vispār sarīkot .."38

Inese Nikuḷceva uzskata, ka Satversmes normas, kas attiecas uz referendumiem, ir novecojušas, turklāt arī likumos tā noregulējums ir radīts, drīzāk lai kavētu, nevis veicinātu tautas nobalsošanu. Ir jāatvieglo vēlētāju parakstu vākšana elektroniski un jāatsakās arī "no vēlētāju parakstu notariālas apliecināšanas". ${ }^{39}$

Gunāra Kūtra ieskatā, tautai ir jādod faktiskas, nevis deklaratīvas tiesības paust savu gribu tautas nobalsošanās. ${ }^{40}$ Jau 1921. gadā Satversmes sapulces loceklis Jānis Rainis izteicās, ka par referendumu Latvijā nevar būt ne runas, jo tās nospiež augstie kvorumi. Raiṇa vārdiem, tautas nobalsošanas "var pie mums notikt visretākos laimes gadijumos. Bet še nav runa par laimi, bet par tiesībām. Pilsonība baidās no tautas nobalsošanas. Man liekas, ka šīs bailes nav pamatotas". Rainis Satversmes sapulcei arī norādīja, ka sekas šai apgrūtinājumu noteikšanai attiecībā uz referendumu rīkošanu būs tautas politiskās izglìtības trūkums, kas attiecīgi novedīs pie demokrātisma trūkuma, bet, ja tauta sajutīs savu spēku, piedaloties referendumos, tas Latvijas valsti darīs vēl stiprāku, jo pašas tautas interesēs taču ir šo valsti uzturēt. Raiņa ieskatā, referendumi ir solis uz tautas izglītību politiskā ziṇā. ${ }^{41}$ Diemžēl tautas nobalsošanām Latvijā ir skumja pieredze, kur pamatoti jāvaino kvorumi un likumu sarežḡîtās organizācijas procedūras. ${ }^{42}$ Jā, tautas nobalsošanas institūts var būt spēcīgs instruments politiskajā cīñā, ${ }^{43}$ jā, Latvijas politika ir l̦oti haotiska, grūti saprotama un grūti vadāma, ${ }^{44}$ taču referendumos tauta atgūst otro elpu un atkal jūtas piederīga savai valstij. ${ }^{45}$ Savukārt, ja tauta atgūs ticību savai valstij, nevis uzskatīs to par nelietderīgu apgrūtinājumu, tad mums vēl ir cerība. Labs piemērs ir čekas maisu neatvēršanas sāga, kas arī sakṇojās politiskās elites bailēs no tautas. Maisus pa specarhīviem mētāja gandrīz trīsdesmit gadus. Maisus galu galā atvēra, un nesmukumi tapa zināmi tautai, taču nekāds sliktums no tā neradās. To pašu var teikt arī par referendumiem...

38 Ozoliņš A. Vienotības piga. Ir, 26.07.-01.08.2012., 6. lpp.

39 N̦ikuḷceva I. Tautas nobalsošana un vēlētāju likumdošanas iniciatīva. Promocijas darbs. Rīga: Latvijas Universitāte, 2012, 206. lpp. Pieejams: https://dspace.lu.lv/dspace/bitstream/handle/7/5120/22881-Inese_Nikulceva_2013.pdf?sequence=1; N̦ikuḷceva I. Fakultatīvā tautas nobalsošana Latvijā un Eiropā. Juridiskās zinātnes aktuālās problēmas. Rīga: Zvaigzne ABC, 2012, 411. lpp.

40 Kūtris G. Referendumi jeb tautas nobalsošanas: cik tas ir reāli. Jurista Vārds, 28.10.2014., Nr. 42.

41 Jānis Rainis. Vispārējās debates par Satversmes I daḷu. IV sesijas 5. sēde 1921. gada 28. septembrī, stenogramma. Latvijas Satversmes sapulces stenogrammu izvilkums 1920-1922). Latvijas Republikas Satversmes projekta apspriešana un apstiprināšana [elektr. izd.]. Rīga: Tiesu namu aǵentūra, 2006, 111.-112. lpp.

42 Pētersons R. Referendums: vēsturiskā pieredze. Neatkarīgā Rīta Avīze, 04.07.1998.

43 Pastars E. Referendumu nedienas. Diena, 03.08.2002.

44 Titavs D. Pieejams: https://www.diena.lv/raksts/viedokli/latvija/prezidentam-nav-jabaidas-bet-jarikojas-14258505?fbclid=IwAR1AU61UEw693PmJaHi7jvEH9sSL0N-yjfm02y9R-r2f0w64BTAeHhu9gL8.

45 Ūdris J. Gunta Ulmaņa vertikāle. Rīga: Jumava, 2009, 206. lpp. 


\section{Kopsavilkums}

Paturot prātā Satversmes pamata panta aizsardzību, uzskatu, ka tautai ir jālauj noticēt savam spēkam. Referendumu tiesības padarìt beidzot Latvijas valstī par reālām ir jābūt tautas priekšstāvju mērḳim. Nepieciešams ieviest "divu līmeņu" konstitucionālus apgrūtinājumus Satversmes grozijumiem. Pirmais būtu esošais apstiprināšanas kvorums "puse no visiem balsstiesīgiem" (Satversmes 79. panta pirmā dal̦a). Kvorumam jāattiecas tikai uz Satversmes pamata pantu (uzskaitīiti Satversmes 77. pantā) grozī̌sanu, kas nozīmētu, ka šai ziṇā saglabātos esošais Satversmes noregulējums. Tomēr uz pārējiem Satversmes pantiem tam nevajadzētu attiekties un to grozīšanai vajadzētu piemērot dalības kvorumā "balsotāju skaits ir puse no pēdējās Saeimas vēlēšanās piedalījušos vēlētāju skaita”. Apstiprināšanas kvorums varētu būt identisks - kā jautājumā par dalību Eiropas Savienībā (Satversmes 79. panta otrais teikums - "vairākums no vēlēšanās piedalījušos vēlētāju skaita"). Manuprāt, Saeimai ir jāizsver pro et contra, nonākot pie viena no secinājumiem - referendums kā lēmuma pieņemšanas metode ir izsmēlis savas iespējas Latvijā, tāpēc no šìs dārgās arhaiskās tradīcijas ${ }^{46}$ jāatsakās pavisam. Vai arī jāpārskata referendumu noregulējums, padarot tos par darboties spējīiem. Visu ciennu platformas "Mana balss" aktivitātēm, bet viṇu "veiksmes stāsts" balstās apstāklī, ka Latvijā nestrādā tiešā demokrātija. ${ }^{47}$

46 Timofejevs P. Referendumi un demokrātija. Diena, 13.09.2003.

47 Diemžēl raksta ierobežotais apjoms nel̦auj aptvert Saeimas ievēlēšanas problemātiku. 